\title{
The influence of anti-HBc status on the sustained virological response rate in HCV-infected patients treated with pegylated interferon alfa 2 and ribavirin
}

\author{
Anna Szymanek-Pasternak', Krzysztof A. Simon 1,2, Sylwia Serafińska ${ }^{1,2}$, Justyna Janocha-Litwin ${ }^{1,2}$, Monika Pazgan-Simon², \\ Grzegorz Madej ${ }^{3}$
}

'I Department of Infectious Diseases, J. Gromkowski Specialistic Regional Hospital, Wrocław, Poland 2Division of Infectious Diseases and Hepatology, Faculty of Medicine and Dentistry, Wroctaw Medical University, Poland ${ }^{3}$ II Department of Infectious Diseases, J. Gromkowski Specialistic Regional Hospital, Wrocław, Poland

\begin{abstract}
Aim of the study: To determine the influence of HBsAg and HBeAg negative but anti-HBc positive status on the sustained virological response (SVR) rate in HCV-infected patients treated with pegylated interferon alfa 2 (Peg-IFNa-2) and ribavirin (RBV).

Material and methods: The study was based on the retrospective analysis of medical records of HCV-infected patients who started Peg-IFN $\alpha$ and RBV treatment between 1 January 2011 and 31 December 2013 at the $1^{\text {st }}$ and $2^{\text {nd }}$ Department of Infectious Diseases of the Regional Hospital in Wroctaw, Poland.

Results: Among 240 patients included in the analysis 99 were anti-HBc positive and 141 anti-HBc negative. In the genotype 1, anti-HBc positive group the SVR rate was $47 \%$ and in the anti-HBc negative group it was $42.7 \%(p=0.591)$. In the genotype 3 , anti-HBc positive group the SVR rate was $60 \%$ and in anti-HBc negative patients it was $63.2 \%(p=0.79)$. Differences in SVR rates between anti-HBc positive and negative groups were not statistically significant. None of the anti-HBc positive patients developed reactivation of $\mathrm{HBV}$ infection during or in the 24 weeks following the end of treatment.
\end{abstract}

Conclusions: Anti-HBC determination does not seem to be useful in predicting treatment outcome of conventional Peg-IFNo/RBV therapy in patients infected with HCV genotypes 1 and 3.

Key words: chronic hepatitis C, HCV infection, HBV occult infection.

\section{Address for correspondence}

Anna Szymanek-Pasternak, I Department of Infectious Diseases, J. Gromkowski Specialistic Regional Hospital, 5 Koszarowa St., 51-149 Wrocław, Poland, phone: +48 605573 562, e-mail: aszymanek7@gmail.com

\section{Introduction}

Both hepatitis B virus (HBV) and hepatitis C virus $(\mathrm{HCV})$ share common routes of transmission, and therefore $\mathrm{HBV} / \mathrm{HCV}$ coinfection is quite common [1]. However, during the acute phase of the infection most adult patients eliminate $\mathrm{HBV}$ while most $\mathrm{HCV}$ patients progress to chronicity. The results of many [2, $3]$ although not all $[4,5]$ studies show the suppressive effect of HCV on HBV replication. Some (10-40\%) [6] individuals who eliminate HBsAg still have HBV DNA present in the liver with detectable or undetectable
HBV DNA in the serum. This situation is called occult HBV infection (OBI).

The influence of OBI on the chronic hepatitis $\mathrm{C}$ outcome and results of chronic hepatitis $C$ therapy is still uncertain [6]. Some authors have observed that chronic hepatitis $\mathrm{C}$ patients with $\mathrm{OBI}$ are at high risk of progression toward cirrhosis and hepatocellular carcinoma (HCC). Moreover, there are studies showing a negative influence of OBI on HCV treatment results with standard interferon monotherapy [7-9]. There are others that show no such effect for pegylated-interferon (Peg-IFN $\alpha)$ and ribavirin (RBV) therapy [10, 
11]. Most studies that concern HBV influence on HCV treatment outcomes refer to HBV DNA, and there are only a few that concern anti-HBc status $[10,11]$. Anti$\mathrm{HBc}$ status may be interesting regarding lower costs of anti-HBc determination compared to HBV DNA or covalently closed circular HBV DNA (ccc HBV DNA) quantification in liver extracts (currently the gold standard for identification of occult HBV genome), although it has to be remembered that some OBI patients are anti-HBc negative [12].

The treatment opportunities for patients with HCV are quickly changing. Clinicians should have the possibility to optimize the selection of patients who may benefit from standard therapy with Peg-IFN $\alpha /$ RBV or Peg-IFN $\alpha / \mathrm{RBV} /$ directly acting agents instead of much more expensive new combinations with interferonfree regimens. This concerns especially settings of limited resources, where full access to new treatments will not be available in the near future.

The aim of the study was to determine the influence of $\mathrm{HBsAg}$ and $\mathrm{HBeAg}$ negative but anti-HBc positive status on the sustained virological response (SVR) rate in HCV-infected patients treated with Peg-IFN $\alpha$ and RBV.

\section{Material and methods}

The study was based on the retrospective analysis of medical records of HCV-infected patients who started Peg-IFN $\alpha$ and RBV treatment between 1 January 2011 and 31 December 2013 at the $1^{\text {st }}$ and $2^{\text {nd }}$ Department of Infectious Diseases of J. Gromkowski Specialist Regional Hospital in Wrocław. Exclusion criteria were HIV co-infection and HBs antigen positive status. Retrospective analysis of available data included: patient age, sex, pre-treatment liver biopsy histological assessment, HCV genotype typing, anti-HBc status, baseline HCV RNA (where available), type of pegylated interferon used for treatment (Peg-IFN $\alpha-2 a$ vs. Peg-IFN $\alpha-2 b)$ and rates of SVR. Patients initiated treatment involving weight adjusted RBV with either Peg-IFN $\alpha-2 \mathrm{a}(180 \mu \mathrm{g} /$ week) or weight adjusted Peg-IFN $\alpha-2 \mathrm{~b}$ for 48 weeks for genotypes 1 and 4 or 24 weeks for genotypes 2 and 3. Standard dose reductions of interferon or ribavirin were performed in the event of anemia, neutropenia or thrombocytopenia. Sustained virological response was defined as undetectable HCV RNA 24 weeks after the completion of therapy. Patients who were lost to follow-up or who had insufficient results to be able to establish successful eradication of HCV, determined by an SVR at least 24 weeks after treatment, were not included for analysis.

The Metavir staging and grading system was used to determine fibrosis and inflammation scores in the histological assessment of pre-treatment liver biop- sies. Subsequently, based on the staging scores patients were divided into groups:

- no or minimal fibrosis (Metavir staging score $<2$ ),

- advanced fibrosis (Metavir staging score $\geq 2$ ).

Based on the grading scores patients were divided into groups:

- no or minimal degree of inflammation (Metavir grading score $<2$ ),

- severe inflammation (Metavir grading score $\geq 2$ ).

Based on baseline HCV RNA level patients were divided into groups of low viral load $(\leq 600000 \mathrm{IU} / \mathrm{ml})$ and high viral load (> $600000 \mathrm{IU} / \mathrm{ml})$.

\section{Statistical analysis}

Data were presented as mean \pm SD (age), mean, median and IQR (baseline HCV-RNA), and percentages for other variables. The $z$-test was used to test for a statistically significant difference between means (age, baseline HCV-RNA). Pearson's $\chi^{2}$ test was used to study independence of all other variables. A $p$-value $<0.05$ was considered significant.

\section{Results}

During the analyzed period of time 393 consecutive HCV-infected patients started Peg-IFNa and RBV treatment. Data on anti-HBc serological status were available for 286 patients and 107 patients had unknown anti-HBc status. 240 patients with known anti- $\mathrm{HBc}$ status completed the treatment and 24 weeks post-treatment follow-up, while 46 patients finished the treatment prematurely for various reasons and were lost to follow-up. Patients lost to follow-up within 24 weeks after treatment as well as those with unknown anti-HBc status were not included in the statistical analysis.

Among 240 patients included in the analysis 99 (41.25\%) were anti-HBc positive and 141 (58.75\%) anti$\mathrm{HBc}$ negative. Baseline characteristics of the patients as well as SVR rates are shown in Table 1.

In the genotype 1 (almost all HCV genotype $1 b$ ), anti-HBc positive group $47 \%$ of patients achieved an SVR, while in the anti-HBc negative group $42.7 \%$ did so. However, this difference was not statistically significant ( $p=0.591, \chi^{2}$ test). In the genotype 3 , anti$\mathrm{HBc}$ positive group the SVR rate was slightly lower (60\%) compared to the genotype 3 , anti-HBc negative patients (63.2\%). This result was not statistically significant either ( $p=0.79, \chi^{2}$ test). For genotype 2 (one patient) and genotype 4 (9 patients) the number of patients was too small for statistical analysis. The relationship between SVR rates and anti-HBc status in genotype 1 and 3 patients is shown in Table 2 . 
Table 1. Baseline characteristics and SVR rates of anti-HBC positive and anti-HBC negative patients

\begin{tabular}{|c|c|c|c|}
\hline Factors & $\begin{array}{c}\text { Anti-HBC (+) } \\
n=99\end{array}$ & $\begin{array}{c}\text { Anti-HBC }(-) \\
n=141\end{array}$ & $p$ \\
\hline Age, mean $\pm S D$ & $48.78 \pm 9.51$ & $49.71 \pm 10.79$ & 0.5545 \\
\hline Treatment experienced & $17(17.2)$ & $34(24.1)$ & 0.2568 \\
\hline Relapsers & $11(64.8)$ & $20(58.8)$ & \\
\hline Null responders & $3(17.6)$ & $6(17.7)$ & 0.9554 \\
\hline Partial responders & $3(17.6)$ & $8(23.5)$ & \\
\hline Male sex, no. (\%) & $59(57.3)$ & $84(61.3)$ & 1.0000 \\
\hline \multicolumn{4}{|l|}{ HCV genotype, no. (\%) } \\
\hline $1(a, b)$ & $66(66.7)$ & $96(68.0)$ & \multirow{3}{*}{0.6577} \\
\hline 3 & $30(30.3)$ & $38(27.0)$ & \\
\hline 4 & $3(3)$ & $7(5)$ & \\
\hline \multicolumn{4}{|l|}{ Staging, no. (\%) } \\
\hline$<2$ & $17(17.1)$ & $28(19.9)$ & \multirow{2}{*}{0.6097} \\
\hline$\geqslant 2$ & $82(82.9)$ & $113(80.1)$ & \\
\hline \multicolumn{4}{|l|}{ Cirrhosis, no. (\%) } \\
\hline$S=4$ & $15(15.2)$ & $34(24.1)$ & 0.1253 \\
\hline \multicolumn{4}{|l|}{ Grading, no. (\%) } \\
\hline$<2$ & $17(17.1)$ & $14(9.9)$ & \multirow{2}{*}{0.1169} \\
\hline$\geqslant 2$ & $82(82.9)$ & $127(90.1)$ & \\
\hline \multicolumn{4}{|c|}{ Baseline HCV-RNA, median, IQR (mean) } \\
\hline Genotype $1(a, b)$ & $1.100 .000,2.407 .500(2.824 .988)$ & $986.500,2.487 .741(2.043 .340)$ & 0.3235 \\
\hline Genotype 3 & $2.100 .000,3.705 .000(4.596 .732)$ & $1.110 .000,3.775 .000(2.694 .631)$ & 0.1404 \\
\hline Genotype 4 & $1.181 .501,485.000(1.103 .834)$ & $1.037 .495,2.050 .000(2.030 .928)$ & $\mathrm{n} / \mathrm{a}$ \\
\hline \multicolumn{4}{|l|}{ Peg-INF $\alpha-2 a, n(\%)$} \\
\hline Genotype $1(a, b)$ & $48(72.7)$ & $64(66.7)$ & 0.4803 \\
\hline Genotype 3 & $20(66.7)$ & $26(68.4)$ & 1,0000 \\
\hline Genotype 4 & $1(33.3)$ & $4(57.1)$ & $\mathrm{n} / \mathrm{a}$ \\
\hline \multicolumn{4}{|l|}{ SVR rate, $n(\%)$} \\
\hline Genotype $1(a, b)$ & $31(47.0)$ & $41(42.7)$ & 0.7073 \\
\hline Genotype 3 & $18(60.0)$ & $24(63.2)$ & 0.8131 \\
\hline Genotype 4 & 0 & $4(57.1)$ & $\mathrm{n} / \mathrm{a}$ \\
\hline
\end{tabular}

n/a - Number of patients in the groups too small for statistical analysis

$z$-test was used to test for statistically significant difference between means (age, baseline HCV-RNA)

Pearson's $\chi^{2}$ test was used to study independence of all other variables

\section{Genotype 1}

Table 3 shows SVR rates in relation to pre-treatment grading and staging scores, baseline HCV load and type of interferon used in anti-HBc positive and negative patients with genotype 1 .
The study showed that pre-treatment grading and staging scores in genotype 1 , anti-HBc positive patients did not have a statistically significant influence on the SVR rate. However, in the anti- $\mathrm{HBc}$ negative group patients with a Metavir staging score $<2$ had a significantly 
Table 2. Sustained virological response (SVR) rate and anti-HBc status in HCV genotype $1(a, b)$ and 3 patients

\begin{tabular}{ccccccccc}
\hline & \multicolumn{3}{c}{ Genotype $1(\mathrm{a}, \mathrm{b})$} \\
\cline { 2 - 9 } & $\begin{array}{c}\text { Anti-HBc (+) } \\
n=66\end{array}$ & $\begin{array}{c}\text { Anti-HBc }(-) \\
n=96\end{array}$ & $\chi^{2}$ & $p$ & $\begin{array}{c}\text { Anti-HBc }(+) \\
n=30\end{array}$ & $\begin{array}{c}\text { Anti-HBc }(-) \\
n=38\end{array}$ & $\chi^{2}$ & $p$ \\
\hline SVR, $n(\%)$ & $31(47)$ & $41(42.7)$ & 0.288 & 0.591 & $18(60)$ & $24(63.2)$ & 0.071 & 0.79 \\
\hline
\end{tabular}

P-value obtained by $\chi^{2}$ test

Table 3. Sustained virological response (SVR) rates in relation to pre-treatment grading and staging scores, baseline HCV load and type of interferon used in anti-HBc positive and negative patients with HCV genotype 1

\begin{tabular}{|c|c|c|c|c|c|c|c|c|c|}
\hline & & \multicolumn{4}{|c|}{$\begin{array}{c}\text { Anti-HBC (+) } \\
n=66\end{array}$} & \multicolumn{4}{|c|}{$\begin{array}{c}\text { Anti-HBc (-) } \\
n=96\end{array}$} \\
\hline & & $n$ & $\begin{array}{c}\text { SVR } \\
n(\%)\end{array}$ & $\chi^{2}$ & $p$ & $n$ & $\begin{array}{c}\text { SVR } \\
n(\%)\end{array}$ & $\chi^{2}$ & $p$ \\
\hline \multirow[t]{2}{*}{ Staging } & $<2$ & 14 & $8(57.1)$ & \multirow{2}{*}{0.738} & \multirow{2}{*}{0.39} & 19 & 12 (63.2) & \multirow{2}{*}{4.049} & \multirow{2}{*}{0.044} \\
\hline & $\geqslant 2$ & 52 & $23(44.2)$ & & & 77 & $29(37.7)$ & & \\
\hline \multirow[t]{2}{*}{ Grading } & $<2$ & 12 & $6(50.0)$ & \multirow{2}{*}{0.054} & \multirow{2}{*}{0.816} & 11 & $10(90.9)^{a}$ & \multirow{2}{*}{11.796} & \multirow{2}{*}{0.00059} \\
\hline & $\geqslant 2$ & 54 & $25(46.3)$ & & & 85 & $31(36.5)^{\mathrm{a}}$ & & \\
\hline \multirow{2}{*}{$\begin{array}{l}\text { Baseline } \\
\text { HCV RNA, } \\
\text { IU/ml }\end{array}$} & $\leqslant 600000$ & 25 & $13(52.0)$ & \multirow{2}{*}{0.409} & \multirow{2}{*}{0.522} & $37^{\mathrm{b}}$ & $20(45.1)$ & \multirow{2}{*}{2.703} & \multirow{2}{*}{0.1} \\
\hline & $>600000$ & 41 & $18(43.9)$ & & & $57^{b}$ & $21(36.8)$ & & \\
\hline \multirow[t]{2}{*}{ Peg-IFN } & Peg-IFN $\alpha-2 a$ & 48 & $25(52.1)$ & \multirow{2}{*}{1.848} & \multirow{2}{*}{0.174} & 64 & $28(43.7)$ & \multirow{2}{*}{0.085} & \multirow{2}{*}{0.77} \\
\hline & Peg-IFN $\alpha-2 b$ & 18 & $6(33.3)$ & & & 32 & $13(40.6)$ & & \\
\hline
\end{tabular}

${ }^{a}$ - $p$ value has limited significance due to too small number of patients in the groups for proper statistical analysis

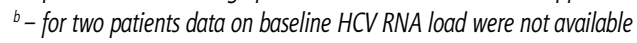

$P$-value obtained by $\chi^{2}$ test

higher SVR rate compared to patients with Metavir $\geq 2$ (63.2\% vs. $37.7 \%, p=0.044)$. In the anti-HBc negative group the statistical analysis of groups divided based on the grading scores was not done due to the small number of patients in the groups.

Based on baseline HCV RNA level patients were divided into two groups: $\leq 600000 \mathrm{IU} / \mathrm{ml}$ and $>600000$ $\mathrm{IU} / \mathrm{ml}$. There was no statistically significant difference between the groups of high and low baseline viral load in the SVR rate in anti- $\mathrm{HBc}$ positive and negative patients.

The differences in SVR rate in anti-HBc positive and negative patients depending on the type of interferon used (Peg-IFN $\alpha$-2a vs. Peg-IFN $\alpha$-2b) were not statistically significant either.

\section{Genotype 3}

Table 4 shows SVR rates in relation to pre-treatment grading and staging scores, baseline HCV load and type of interferon used in anti-HBc positive and negative patients with genotype 3 .

In the genotype 3 , anti-HBc negative group patients with a baseline HCV RNA level $\leq 600000 \mathrm{IU} /$ $\mathrm{ml}$ had a higher SVR rate than patients with viral load $>600000 \mathrm{IU} / \mathrm{ml}$ (71.4\% vs. $58.3 \%)$. This difference was not statistically significant $(p=0.42)$.

Statistical analysis of SVR rate in relation to baseline grading and staging scores and type of interferon used for treatment in anti-HBc positive and negative patients as well as analysis of SVR rate in relation to baseline viral load in anti-HBc positive patients was not done due to the small number of patients in the groups.

After successful anti-HCV therapy none of the anti$\mathrm{HBc}$ positive patients with SVR developed chronic hepatitis $\mathrm{B}$.

\section{Discussion}

In our study prevalence of anti-HBc positivity in HCV-infected patients was $41.25 \%$. This high number may result from the common route of transmission for these two infections. The overall prevalence of markers of HBV infection in Poland is $16.6 \%$ and has decreased rapidly since the program of vaccinations in newborns was implemented in 1996 [13]. 
Table 4. Sustained virological response (SVR) rates in relation to pre-treatment grading and staging scores, baseline HCV load and type of interferon used in anti-HBc positive and negative patients with genotype 3

\begin{tabular}{|c|c|c|c|c|c|c|c|c|c|}
\hline & & & $\begin{array}{c}\text { Anti-HB } \\
\quad n=3\end{array}$ & & & & $\begin{array}{r}\text { Anti-HB } \\
n=3\end{array}$ & & \\
\hline & & $n$ & SVR, $n(\%)$ & $\chi^{2}$ & $p$ & $n$ & SVR, $n(\%)$ & $\chi^{2}$ & $p$ \\
\hline Staging & $<2$ & 3 & $3(100)^{a}$ & & & 8 & $6(75)^{a}$ & & \\
\hline & $\geqslant 2$ & 27 & $15(55.6)^{a}$ & & & 30 & $18(60)^{\mathrm{a}}$ & & \\
\hline Grading & $<2$ & 5 & $3(60)^{a}$ & & & 3 & $2(66.7)^{a}$ & & \\
\hline & $\geqslant 2$ & 25 & $15(60)^{\mathrm{a}}$ & & & 35 & $22(62.9)^{a}$ & & \\
\hline Baseline & $\leqslant 600000$ & 8 & $6(75)^{a}$ & & & 14 & $10(71.4)$ & & \\
\hline $\mathrm{IU} / \mathrm{ml}$ & $>600000$ & 22 & $12(54.5)^{a}$ & & & 24 & $14(58.3)$ & 0.652 & 0.42 \\
\hline Peg-IFN & Peg-IFN $\alpha-2 a$ & 20 & $13(65)^{a}$ & & & 26 & $16(61.5)^{a}$ & & \\
\hline & Peg-IFN $\alpha-2 b$ & 10 & $5(50)^{a}$ & & & 12 & $8(66.7)^{a}$ & & \\
\hline
\end{tabular}

a - Number of patients in the groups to small for statistical analysis

P-value obtained by $\chi^{2}$ test

The study shows lack of association between anti$\mathrm{HBC}$ status and response to peg-IFN/RBV treatment in HCV genotype 1 and 3 infected patients. Similar findings were reported by Levast et al. [10] in retrospective analysis of $140 \mathrm{HCV}$-infected patients. Furthermore, Levast et al. reported that presence of anti-HBc was not associated with pre-therapeutic HCV viral load, ALT serum levels, histological activity or fibrosis. Therefore these authors concluded that it does not appear useful to screen for anti-HBc status before beginning HCV treatment with peg-IFN alfa and RBV. Opposite results were obtained by Emara et al. [11] in 155 Egyptian chronic HCV patients. These authors concluded that anti-HBc was associated with poor response to the peg-IFN/RBV therapy as well as with higher baseline $\mathrm{HCV}$ viral load, while it had no relation to histological indices (fibrosis and activity). These authors, however, did not determine the HCV genotype in their patients or HBV DNA liver tissue status. In Egypt genotype 4 is most prevalent, while in our cohort only 10 patients had that genotype and statistical analysis was performed only for genotypes 1 and 3 .

In our study in the genotype 1 , anti-HBc negative group, patients with a lower fibrosis score (Metavir $<2$ ) had a significantly higher SVR rate than those with advanced fibrosis. This result is in agreement with most previous studies that show a strong negative correlation between fibrosis and treatment response in the general population of $\mathrm{HCV}$-infected patients [14-18]. Interestingly, in our study in the genotype 1 , anti-HBc positive group there was no link between response to the combination therapy and fibrosis severity in pre-treatment liver histology.
There are no studies comparing SVR rates depending on activity score or fibrosis severity in anti-HBc positive patients. Moreover, there was no significant association between baseline HCV RNA and SVR rate either in genotype 1 anti-HBc positive, anti-HBc negative or genotype 3 anti-HBc negative patients. These results are in contrast to most previous studies that show an association between high viral load and poor treatment results [17-19]. Due to the limited funds we did not determine ILB-28 polymorphisms in our patients. However, according to previous studies in a Polish HCV-infected population the genotypic frequency of rs $12979860 \mathrm{CC}$ ranges between 20 and 43\%, CT 46.5-57.14\% and TT 10.5-27\% [20-23].

In our study after successful anti-HCV therapy none of the anti-HBc positive patients with SVR developed HBV reactivation. This probably results from the suppressive effect of interferon on HBV replication. On the other hand, cases of possible HBV reactivation after HCV therapy with DAA have already been reported by some authors [24-26].

Due to the possibility of $\mathrm{HBV}$ reactivation after HCV elimination, special caution should be considered in patients treated with novel, interferon-free regimens in the group of anti-HBc positive patients, especially because, contrary to the interferon-based therapies, these new therapies have no influence on HBV replication. Moreover, it has to be remembered that even HCV elimination and HBV suppression do not eliminate entirely the risk of fibrosis progression or HCC [27] and in cost-effectiveness evaluation of HCV treatment, apart from liver fibrosis the risk of HBV reactivation may also be taken into account [28]. 


\section{Conclusions}

Anti-HBc determination does not seem to be useful in predicting treatment outcome of conventional Peg-IFN/RBV therapy in patients infected with HCV genotype 1 or 3 .

\section{Disclosure}

Authors report no conflict of interest.

\section{References}

1. Mohamed Ael E, al Karawi MA, Mesa GA. Dual infection with hepatitis C and B viruses: clinical and histologic study in Saudi patients. Hepatogastroenterology 1997; 44: 1404-1406.

2. Schuttler CG, Fiedler N, Schmidt K, et al. Suppression of hepatitis $B$ virus enhancer 1 and 2 by hepatitis $C$ virus core protein. J Hepatol 2002; 37: 855-862.

3. Chen SY, Kao CF, Chen CM, et al. Mechanisms for inhibition of hepatitis $\mathrm{B}$ virus gene expression and replication by hepatitis $\mathrm{C}$ virus core protein. J Biol Chem 2003; 278: 591-607.

4. Zarski JP, Bohn B, Bastie A, et al. Characteristic of patients with dual infection by hepatitis B and C viruses. J Hepatol 1998; 28: 27-33.

5. Pontisso P, Gerotto M, Ruvoletto MG, et al. Hepatitis C genotypes in patients with dual hepatitis $\mathrm{B}$ and $\mathrm{C}$ virus infection. J Med Virol 1996; 48: 157-160.

6. Raimondo G, Allain JP, Brunetto MR, et al. Statements from the Taormina expert meeting on occult hepatitis B virus infection. J Hepatol 2008; 49: 652-657.

7. Squadrito G, Cacciola I, Alibrandi A, et al. Impact of occult hepatitis $B$ virus infection on the outcome of chronic hepatitis C. J Hepatol 2013; 59: 696-700.

8. Zignego A, Fontana R, Puliti S, et al. Impaired response to alpha interferon in patients with an inapparent hepatitis B and hepatitis C virus coinfection. Arch Virol 1997; 142: 535-544.

9. Fukuda R, Ishimura N, Niigaki M, et al. Serologically silent hepatitis $B$ virus coinfection in patients with hepatitis $C$ virus-associated chronic liver disease: clinical and virological significance. J Med Virol 1999; 58: 201-207.

10. Levast M, Larrat $S$, Thelu MA, et al. Prevalence and impact of occult hepatitis B infection in chronic hepatitis $C$ patients treated with pegylated interferon and ribavirin. J Med Virol 2010; 82: 747-754.

11. Emara MH, El-Gammal NE, Mohamed LA, et al. Occult hepatitis B infection in egyptian chronic hepatitis $C$ patients: prevalence, impact on pegylated interferon/ribavirin therapy. Virol J 2010; 7: 324.

12. Borzooy Z, Jazayeri SM, Mirshafiey A, et al. Identification of occult hepatitis B virus (HBV) infection and viral antigens in healthcare workers who presented low to moderate levels of antiHBs after HBV vaccination. Germs 2015; 5: 134-140.

13. Czerwiński J, Malanowski P, Wasiak D, et al. Viral hepatitis B and $\mathrm{C}$ markers in the population of deceased donors in Poland. Transplant Proc 2007; 39: 2695-2697.

14. Bourgeois S, Deltenre P, Delwaide J, et al. A non-interventional phase IV Belgian survey to assess the antiviral effectiveness of pegylated interferon-alpha- $2 \mathrm{~b}$ and ribavirin treatment according to the stage of liver fibrosis in previously untreated patients with genotype 1/4/5/6 chronic hepatitis C (PRACTICE). Acta Gastroenterol Belg 2014; 77: 393-400.
15. Boglione L, Cusato J, Cariti G, et al. Treatment optimization of naïve HCV-1 patients using IL28B, RVR and fibrosis stage. Antiviral Res 2015; 116: 45-47.

16. Andriulli A, Nardi A, Di Marco V, et al. An a priori prediction model of response to peginterferon plus ribavirin dual therapy in naïve patients with genotype 1 chronic hepatitis C. Dig Liver Dis 2014; 46: 818-825.

17. Lindh M, Arnholm B, Eilard A, et al. Hepatitis C treatment response kinetics and impact of baseline predictors. J Viral Hepat 2011; 18: 400-407.

18. Poynard T, McHutchison J, Goodman Z, et al. Is an "a la carte" combination interferon alfa- $2 \mathrm{~b}$ plus ribavirin regimen possible for the first line treatment in patients with chronic hepatitis $\mathrm{C}$ ? The ALGOVIRC Project Group. Hepatology 2000; 31: 211-218.

19. Gheorghe L, Iacob S, Grigorescu M, et al. High sustained virological response rate to combination therapy in genotype $1 \mathrm{pa}-$ tients with histologically mild hepatitis C. J Gastrointestin Liver Dis 2009; 18: 51-56.

20. Cieśla A, Bociąga-Jasik M, Sobczyk-Krupiarz I, et al. IL28B polymorphism as a predictor of antiviral response in chronic hepatitis C. World J Gastroenterol 2012; 18: 4892-4897.

21. Bukowska-Ośko I, Radkowski M, Pawełczyk A, et al. Hepatitis C virus 5' untranslated region variability correlates with treatment outcome. J Viral Hepat 2014; 21: 551-559.

22. Domagalski K, Pawlowska M, Tretyn A, et al. Association of IL28B Polymorphisms With the Response to Peginterferon Plus Ribavirin Combined Therapy in Polish Patients Infected With HCV Genotype 1 and 4. Hepat Mon 2013; 13: e13678.

23. Domagalski K, Pawłowska M, Zaleśna A, et al. The relationship between IL-28B polymorphisms and the response to peginterferon alfa-2a monotherapy in anti-HBe-positive patients with chronic HBV infection. Eur J Clin Microbiol Infect Dis 2014; 33: 2025-2033.

24. Hayashi K, Ishigami M, Ishizu Y, et al. A case of acute hepatitis $B$ in a chronic hepatitis $C$ patient after daclatasvir and asunaprevir combination therapy: hepatitis $B$ virus reactivation or acute self-limited hepatitis? Clin J Gastroenterol 2016; 9: 252-256.

25. Takayama H, Sato T, Ikeda F, et al. Reactivation of hepatitis B virus during interferon-free therapy with daclatasvir and asunaprevir in patient with hepatitis B virus/hepatitis C virus coinfection. Hepatol Res 2016; 46: 489-491.

26. Wang C, Ji D, Chen J, et al. Hepatitis due to Reactivation of Hepatitis B Virus in Endemic Areas Among Patients With Hepatitis C Treated With Direct-acting Antiviral Agents. Clin Gastroenterol Hepatol 2016; doi: 10.1016/j.cgh.2016.06.023 [Epub ahead of print].

27. Munteanu M. Biomarker panels and regression of fibrosis in chronic viral hepatitis. GERMS 2015; 5: 115.

28. Maan R, Zaim R, van der Meer AJ, et al. Real-world medical costs of antiviral therapy among patients with chronic HCV infection and advanced hepatic fibrosis. J Gastroenterol Hepatol 2016; doi: 10.1111/jgh.13373 [Epub ahead of print]. 